\title{
Readabilty in management reports: extension and good governance practices
}

\author{
Álvaro Melón-Izco ${ }^{a}$, Francisco J. Ruiz-Cabestre ${ }^{\mathrm{b}}$, Carmen Ruiz-Olalla ${ }^{\mathrm{c}}$
}

$a, b, c)$ Departamento de Economía y Empresa. Universidad de la Rioja. Logroño, La Rioja, España.

${ }^{a}$ Corresponding author.

E-mail address: alvaro.melon@unirioja.es

\section{A R T I C LE I N F O}

\section{Article history:}

Received 18 February 2019

Accepted 14 September 2019

Available online 1 January 2021

\section{JEL classification:}

M4

M40

M41

M48

G3

G38

\section{Keywords:}

Readability

Fernández Huerta index

Good governance practices

Management report

Non-financial information

Narrative information

Códigos JEL:
M4
M40
M41
M48
G3

G38

Palabras clave:

Legibilidad

Índice de Fernández Huerta

Prácticas de buen gobierno

Informe de gestión

Información no financiera

Información narrativa

\section{A B S T R A C T}

This study expands our knowledge about the readability of accounting narratives, their extension and companies compliance with good governance practices. It also covers a gap in the analysis of the readability of narrative information written in Spanish. We examined the readability in Management Reports of Spanish companies listed on the Continuous Market of the Madrid Stock Exchange during the period 20102016 The results reveal that the most extensive management reports that is, those with the greatest quantities of text are the least readable and that the use of visual elements in reports helps to improve their readability. Moreover, companies that follow good governance practices issue complex information with clarity, speed, and simplicity, which improves the readability of accounting narratives.

(C)2021 ASEPUC. Published by EDITUM - Universidad de Murcia. This is an open access article under the CC BY-NC-ND license (http://creativecommons.org/licenses/by-nc-nd/4.0/).

La legibilidad en los informes de gestión: extensión y buenas prácticas de gobierno corporativo

R E S U M E N

Este estudio expande el conocimiento sobre la legibilidad de los informes contables, su extensión y el cumplimiento de las empresas con las prácticas de buen gobierno. También cubre un vacío en el análisis de la legibilidad de la información narrativa escrita en español. Examinamos la legibilidad en los Informes de Gestión de las empresas españolas que cotizan en el Mercado Continuo de la Bolsa de Madrid durante el período 2010-2016. Los resultados revelan que los informes de gestión más extensos, es decir, aquellos con mayor cantidad de texto, son los menos legibles, y que el uso de elementos visuales en los informes ayuda a mejorar su legibilidad. Además, las empresas que siguen prácticas de buen gobierno, emiten información compleja con claridad, velocidad y simplicidad, lo que mejora la legibilidad de los informes contables.

(C2021 ASEPUC. Publicado por EDITUM - Universidad de Murcia. Este es un artículo Open Access bajo la licencia CC BY-NC-ND (http://creativecommons.org/licenses/by-nc-nd/4.0/). 


\section{Introduction}

This paper provides new evidence on the readability of accounting narrative information in the Spanish language. As a novelty, we demonstrate the relationship between readability and two characteristics that define the extension of accounting narratives, such as the quantity of text and visual elements, and also the relationship with respect to good corporate governance practices. These two relationships constitute the objectives of this study.

'Readability' and 'legibility' are intrinsic elements that have an impact on the ease and speed of reading a text. The first has to do with the style in which a message is written (basically the length of words and sentences). The second refers to visually engaging with the text (size, typeface, margins and spaces, among others). This study focuses on readability and adds to the growing literature currently investigating the language used in accounting disclosures (Asay, Libby, \& Rennekamp, 2018; Bonsall, Leone, Miller, \& Rennekamp, 2017; Li, 2008; Lim, Chalmers, \& Hanlon, 2018; Lo, Ramos, \& Rogo, 2017; Loughran \& McDonald, 2014; Moreno \& Casasola, 2016; Suárez Fernández, 2016).

As annual reports have expanded, the complexity of accounting narratives is being questioned more intensely. The complexity of the disclosures made by companies has led regulatory bodies to initiate projects to improve the readability (Lim et al., 2018) and to reduce the size of annual reports. Organisations such as the Securities and Exchange Commission (SEC, 1998) have proposed limiting the number of pages allowed in the reports based on factors such as the industry and the size of the company. They have also contemplated the use of readability indices, such as Fog's, to help improve the reading of financial documents (Loughran \& McDonald, 2014). However, for these authors, interest should not be focused on the style of writing (readability), but on writing more concise documents. The concern of some regulatory bodies like the SEC about the length of documents and their readability leads us to analyse whether the quantity of text and the quantity of visual elements that define their extension really affect their readability, that is, if these two characteristics of the documents affect readability. One the one hand, the shorter texts are easier to read (Loughran \& McDonald, 2014) and, on the other hand, graphic resources, which are also expanding, (Beattie \& Jones, 1997; Havemo, 2018) serve to "support the information and reasoning presented in paragraphs of a narrative nature" (CNMV, 2013, p. 35), both affecting readability.

An important part of the research has focused on associating readability with the characteristics of the companies, mainly with financial performance (Asay et al., 2018; Bushee, Gow, \& Taylor, 2018; Guay, Samuels, \& Taylor, 2016; Li, 2008), and to a lesser extent with other characteristics such as corporate governance mechanisms (Cerbioni \& Parbonetti, 2007; Ginesti, Drago, Macchioni, \& Sannino, 2018; Suárez Fernández, 2016; Velte, 2018). However, in this study we focus on investigating whether good governance practices, contained in the unified code of good governance, explain the readability of accounting narratives, since good governance practices have become a tool that encourages companies to increase their transparency (Mallin, 2013). If so, transparency will be transmitted to accounting narratives, which will disclose complex information with more clarity, speed and simplicity (readability). Consequently, our proposal is that good governance practices, by positively influencing transparency, affect the communications made by companies and, therefore, the readability of the accounting narratives they provide.

In this context we present our work for the Spanish case. The aim is to analyse the readability of non-financial information contained in Management Reports ${ }^{1}$. In particular, we analyse whether the quantity of text and visual elements, that determine the extension of management reports, and compliance of good governance practices, included in the Annual Corporate Governance Report ${ }^{2}$, explain the readability of these reports. To this end, we have analysed a total of 595 management reports of Spanish listed companies during the period 2010-2016. Readability is measured with the Fernández Huerta index, developed especially to analyse the readability of texts in Spanish, since the classic indices based on English (i.e., the Fog and Flesch indices) are not suitable ${ }^{3}$. As a preliminary result, we find that management reports that present more text are less readable, and that the use of visual elements helps to improve the readability of these documents. Finally, we demonstrate that companies that follow a greater number of good governance practices are those that issue more readable information.

Our work makes several contributions. First, it extends knowledge about the readability of accounting narratives, their extension and companies' compliance with good governance practices, since we have not found any paper that relates these variables in the literature. In particular, it illustrates evidence of the relationship between the readability and two characteristics that define the extension of management reports, such as the amount of text and visual elements, since those more concise reports and that has the support of more visual elements will be easier to read. The relationship with good governance practices is also analysed, since it is expected that transparency and therefore readability will be greater in those companies that comply with a greater number of good governance recommendations. Second, it adds to the papers of Fialho, Fuertes \& Pascual (2002), Suárez Fernández (2013, 2016) and Moreno \& Casasola (2016) to cover a gap in the study of the readability of narrative information written in Spanish, being the first paper that analyses readability in Spain during a current post-crisis period and uses a large sample of listed companies (practically the entire population of companies). It is important to note that most papers that analyse readability have focused on documents written in English and in English-speaking countries. In addition, it is important to remember that Spanish is the second language of communication in the world (Instituto Cervantes, 2017). Third, it analyses the management report of Spanish listed companies, a document that has not received the attention it deserves, in spite of the fact that it is a mandatory report for those companies and so adds value to the study.

Our results may be of interest to the regulatory bodies that issue standards that are concerned with improving the readability of financial reports, since they must take into account that, according to our findings, this improvement depends on the quantity of text and visual elements contained in the reports and on whether or not companies comply with good governance practices. It may also interest those responsible for preparing financial information, as well as analysts and

${ }^{1}$ The Management Report of the European Unión is equivalent to the Management Commentary of the IASB, the Management Discussion and Analysis (MD\&A) of the United States of America (USA) and Canada and the Operational and Financial Review of the United Kingdom (UK).

${ }^{2}$ The Securities Market Law in Spain establishes that listed companies must make public an Annual Corporate Governance Report and disseminate it as a relevant event, detailing the degree of compliance with the recommendations of the Unified Code.

${ }^{3}$ The indices are not suitable when taking into account the differences between the languages, both in length and linguistic style (Ngai \& Singh, 2014). 
general users of this kind of information.

The remainder of the paper is organised as follows. We provide background and develop hypotheses in section 2 . The methodology used and the research design are then discussed in section 3 . In section 4 , the main results are presented. The work ends with the conclusions reached in section 5 .

\section{Background and hypotheses development}

As the accounting narratives disclosed by companies is expanding, the complexity of these documents is questioned. That is, "Because many investors are neither lawyers, accountants, nor investment bankers, we need to start writing disclosure documents in a language investors can understand ... The legalese and jargon of the past must give way to everyday words that communicate complex information clearly ... Brokers and investment advisers can make better recommendations to their clients if they can read and understand these documents quickly and easily" (SEC, 1998, p. 9). This has prompted the international financial reporting community to initiate projects on streamlining annual reports to improve their readability (Lim et al., 2018). For the Spanish case, Suárez Fernández (2016) suggests the publication of a guide of good practices that helps companies to elaborate narrative information in a more understandable way, following the example of documents elaborated in the United States or in England. The usefulness of corporate disclosure depends on readability and understandability (Ajina, Laouiti, \& Msolli, 2016).

Readability relates to the text's inherent capability of being read quickly and easily (Schroeder \& Gibson, 1990). Readability formulas have been frequently used in the literature in several fields of knowledge. Their implementation is simple, quick and inexpensive (Courtis, 1987), as well as being passive, so reader participation is not required (Jones, 1997).

Most formulas are based on two variables - the number of syllables per word (semantic variable) and the number of words per sentence (syntactic variable) - that predict how readable a text will be (Courtis, 1986). The first measures semantic difficulty and recognition speed, whereas the second measures the burden on short-term memory (Smith \& Taffler, 1992). The resulting scores can be interpreted against a scale of difficulty (Jones, 1997), where for the Flesch Reading Ease Formula (FREF), for example, high scores indicate reading ease (or a low educational level required for reading) and low scores indicate reading difficulty (or a high educational level required for reading).

Some of the most widely used formulas in the literature henceforth called indices - to analyse the readability of accounting narratives are the Flesch index (Flesch, 1948) and the Gunning Fog Index or Fog Index (Gunning, 1952). The results of research in this topic are quite similar, concluding that accounting documents can be classified as difficult or very difficult to read within this scale of difficulty (Clatworthy \& Jones, 2001; Courtis, 1995; Dolphin \& Wagley, 1977; Lewis, Parker, Pound, \& Sutcliffe, 1986; Loughran \& McDonald, 2014; Smith \& Taffler, 1992; Soper \& Dolphin, 1964). Loughran \& McDonald (2014) used the Fog index to measure the readability of $10-\mathrm{K}$ filings, which they considered illegible. Despite the difficulty due to the use of technical business language, these authors pointed out that experienced readers of these types of documents are unlikely to consider them difficult to read.

\subsection{Readability evolution}

The literature has also used these indices to analyse the evolution of the readability of accounting narratives over time. The most widespread conclusion, when working with small samples of companies, is that documents are becoming increasingly difficult to read (Courtis, 1995; Dolphin \& Wagley, 1977; Jones, 1988; Lewis et al., 1986; Soper \& Dolphin, 1964). However, when large samples of companies have been used in the analysis, the results are inconclusive. Li (2008) observed that annual reports after 1999 improved in readability until 2002, when they became even more difficult to read than before 1999. On the other hand, Loughran \& McDonald (2014) found that readability was similar in the two periods analysed, from 1994 to 2002 and from 2003 to 2011. Suárez Fernández (2016) also found that readability was similar during the years 2007, 2008 and 2009. With this background of mixed evidence, we propose the first hypothesis:

H1: The readability of the narrative information contained in management reports does not change over time.

\subsection{Readability and quantity of text and visual elements}

It should also be noted that accounting narrative information released by companies has been expanding in recent decades (Beattie \& Davison, 2015; Beattie, McInnes, \& Fearnley, 2004; Beattie \& Smith, 2013; Tarca \& Seah, 2006). There has been an increase in the number of words (Li, 2008) and an increase in visual resources (i.e., tables, images, graphs and figures), which has caused documents to increase in size over time (Loughran \& McDonald, 2014).

Therefore, we wonder whether including more text affects the readability index scores of the documents. A portion of the literature has tried to justify that more text implies lower readability. Li (2008) has suggested that reports that contain more text also require higher information-processing costs and seem to be more difficult to read, since the length of reports could be used by managers to make reports less transparent. It also seems that the information on bad news is less readable than for good news, since such information is masked by more complex texts (Asay et al., 2018; Bushee et al., 2018; Guay et al., 2016; Li, 2008). Loughran \& McDonald (2014) consider that those companies that try to hide information are more likely to go unnoticed if they use more extensive documents. It is not surprising that these authors recommend that the SEC encourage managers to write more concisely, since documents written in this way are more likely to be easier to read. As part of the explanations that relate the amount of text with readability may be motivated by firm size or by different techniques of manipulation of narrative information (such as impression management, management obfuscation and/or incomplete revelation) in the face of poor performance, it will be necessary to control the analysis by the firm size and its performance. We also incorporate other control variables that could be behind this relationship.

Based on the work of Li (2008) and Loughran \& McDonald (2014), together with the lack of empirical evidence relating these two variables (i.e., text quantity and readability), we formulate the second hypothesis:

H2: Management reports that contain greater quantities of text are more difficult to read.

Naturally, this hypothesis corresponds to a very broad readability approach, based on Li (2008), where longer texts are more deterring and require higher costs of informationprocessing, and Loughran \& McDonald (2014), who argued 
readability is defined as the ability to assimilate valuationrelevant information. In a traditional approach based on readability indices, such as the Flesch index (Flesch, 1948) or the Fog index (Gunning, 1952), where readability is measured on the length of words and sentences, this is not so obvious, since those longer reports with short words and sentences will be more readable.

On the other hand, Hopwood (2007) has identified a radical transformation in accounting narratives, evolving from minimalist legal documents to creative documents that often combine text, images, graphics and other elements. This is motivated and encouraged by organisations such as the SEC (1998), the International Organization of Securities Commissions (IOSCO, 2003), the IASB $(2006,2010)$ and the National Securities Market Commission (CNMV, 2013) that propose the use of visual elements as a tool that allows companies to write simpler and more readable reports.

Taking into account the above in relation to the quantity of visual elements and readability, and again being aware of the lack of empirical evidence, we consider the third hypothesis:

H3: The use of visual elements (i.e., tables, charts, graphs, figures, maps, flowcharts and other graphics) allows companies to create management reports that are easier to read.

\subsection{Readability and good governance practices}

In the current scenario of uncertainty and recent financial scandals, it is necessary to increase the transparency of the information published by companies in order to reduce information asymmetries. One of the principles of corporate governance established by the OCDE (2016) is the disclosure of information and transparency. This principle requires, among other information minimums, the disclosure of non-financial information, usually as an integral part of company's management report. In this sense, the readability of corporate disclosures is crucial to mitigate the information asymmetry and improve stakeholders' perception of the firm (Ginesti et al., 2018).

Previous literature has investigated the influence of various factors of corporate governance on the disclosure of information. Bravo \& Reguera-Alvarado (2017) have documented a positive association between board independence and financial reporting quality. Yekini et al. (2015) indicate a statistically significant relationship between board independence and the quality of community disclosures. Liu \& Zhang (2017) have demonstrated a positive correlation between state-owned shareholding ratio, number of directors, number of meetings of the supervisory board and proportion of managerial staff shareholding, and the level of disclosure of social responsibility information; while the share ratio of the largest shareholder has a negative correlation. Wang (2016) also concluded that corporate governance has a positive correlation to the value of disclosure of environmental information.

On the other hand, the literature has also focused on associating readability with the characteristics of companies, mainly financial performance (Asay et al., 2018; Bushee et al., 2018; Guay et al., 2016; Li, 2008), measured through several variables such as earnings persistence (Li, 2008; Lo et al., 2017), profitability (Dempsey, Harrison, Luchtenberg, \& Seiler, 2012; Moreno \& Casasola, 2016), or stock return volatility, analyst forecast dispersion and analyst earnings forecast accuracy (Loughran \& McDonald, 2014; Bonsall et al., 2017). To a lesser extent, attempts have also been made to associate readability with other firm characteristics, such as corporate governance mechanisms (Cerbioni \& Parbonetti, 2007; Gin- esti et al., 2018; Suárez Fernández, 2016; Velte, 2018). However, we have not found empirical evidence that associates readability with compliance with good governance practices.

The good governance codes aim to provide solutions to the asymmetric information problems between managers and shareholders. Kaspereit et al. (2017) suggested that investors who operate in markets with asymmetric information are more interested in the actions of companies that achieve high levels of corporate governance. The good governance codes contain recommendations on good governance practices, which improve the effectiveness of companies in terms of corporate governance and increase their legitimacy before investors (Zattoni \& Cuomo, 2008). For this, good governance practices are a tool that facilitates the creation of an environment of trust, transparency and accountability (Mallin, 2013; OCDE, 2016). In this sense, Pucheta-Martínez \& Narro-Forés (2014) argued that good governance practices arise to improve business management with principles such as transparency, which translates into clearer and more reliable information, increasing stakeholder confidence. If so, transparency will be transmitted to accounting documents, which will become more readable, since good corporate governance practices try to avoid the opportunistic behaviour of managers, who are tempted to take advantage of information asymmetries with respect to stakeholders (Cuomo, Mallin, \& Zattoni, 2016; Fama \& Jensen, 1983). Therefore, we propose the last hypothesis:

H4: Companies that comply with a greater number of the recommendations of good governance practices issue more readable management reports.

\section{Research design and methodology}

\subsection{Data}

Our database contains the management reports of listed firms on the Continuous Market of the Madrid Stock Exchange during the period 2010-2016. All companies belonging to the financial and real estate sectors - namely banks, insurance companies, real estate companies and investment companies - were eliminated. The use of this first filter was justified by the special characteristics of these types of firms because the National Stock Market Commission makes specific recommendations for them that are different from the general recommendations given for the other companies analysed in this paper. Firms subjected to liquidation in the years examined were eliminated because liquidation could lead to abnormal behaviour in the publication of their information. In a third filter, companies that did not have information on their consolidated annual accounts were deleted, either because they presented only individual annual accounts or because they were foreign companies without an obligation to publish accounting documents in Spain. We also only considered companies with at least five consecutive years of available information to provide greater efficiency in the estimates of the panel data models. As a result, we have an unbalanced panel of 87 listed Spanish companies with 595 observations of consolidated management reports for the period 2010-2016 (see Table 1).

Although management reports are one of the main documents with narrative information that Spanish firms produce, its content and structure is practically voluntary, owing to the lack of laws or guidelines to standardise its format and regulate its extent, epigraphs, and degree of detail, with the exception of the Guide for the Preparation of the Management Report of Listed Companies (CNMV, 2013), which was imple- 
Table 1

Sample description

\begin{tabular}{|c|c|c|c|c|c|c|c|c|}
\hline \multirow{2}{*}{ Step } & \multirow{2}{*}{ Filter } & \multicolumn{7}{|c|}{ Numbers of firms } \\
\hline & & 2010 & 2011 & 2012 & 2013 & 2014 & 2015 & 2016 \\
\hline Initial sample & Total Spanish listed companies & 141 & 146 & 141 & 137 & 153 & 152 & 148 \\
\hline First filter & $\begin{array}{l}\text { Financial and real estate } \\
\text { companies }\end{array}$ & -39 & -41 & -37 & -36 & -44 & -42 & -38 \\
\hline Second filter & Liquidated companies & -4 & -4 & -3 & -3 & -3 & -1 & \\
\hline Third filter & $\begin{array}{l}\text { Companies without consolidate } \\
\text { data }\end{array}$ & -8 & -10 & -10 & -9 & -13 & -14 & -16 \\
\hline Fourth filter & $\begin{array}{l}\text { Companies with less than five } \\
\text { consecutive observations }\end{array}$ & -7 & -5 & -4 & -2 & -6 & -11 & -13 \\
\hline Final sample & & 83 & 86 & 87 & 87 & 87 & 84 & 81 \\
\hline
\end{tabular}

This table shows the process used to debug the database for the period 2010-2016

mented in 2014 and its compliance is voluntary for companies.

The data related to the dependent variable (readability), the independent variables (quantity of text and visual elements) and the control variable (compliance with the CNMV guide for the elaboration of management reports) were collected from the management reports, while those corresponding to compliance with good practices were taken from the annual corporate governance reports. Finally, the financial information corresponding to the rest of the control variables (firm characteristics) were obtained from the SABI database.

\subsection{Readability analysis}

As we anticipated, the indices most frequently used in the literature to analyse the readability of accounting documents have been the Flesch index (Flesch, 1948) and the Fog index (Gunning, 1952). However, these indices were developed for English texts, so their application in Spanish texts is meaningless (Fernández Huerta, 1959; Rabin, 1988). As an example, the words in English are shorter and, therefore, would be considered as easier to read than words in Spanish according to these indices (Jones \& Shoemaker, 1994). Sentences in Spanish also have a greater number of words (Fialho et al., 2002), so they would be considered more difficult to read according to these indices. Following Moreno \& Casasola (2016), we used two adaptations to the Spanish of the original Flesch index, the Flesch-Fernández Huerta index or the Fernández Huerta index (Fernández Huerta, 1959) and Flesch-Szigriszt index or Szigriszt index (Szigriszt Pazos, 1992). As both indices are highly correlated, we initially chose the Fernández Huerta index to make the estimates, due to its wider use. However, in order to provide robustness, we repeated all the regressions with the Szigriszt index as dependent variable, as will be illustrated later.

The readability analysis of the reports was carried out in several steps. First, the consolidated annual accounts of all the companies were obtained for the years 2010-2016, to extract from them the consolidated management reports (595 in total) that were analysed. These documents were converted to Word format for later text processing. Second, all visual elements were removed and a fragment of each management report representing $10 \%$ of the total text of document was randomly selected ${ }^{4}$. We chose to analyse a similar percentage for all documents instead of a specific number of words, to ensure that all the texts analysed represented the same proportion of the total document. Once the part of the management report to be analysed was chosen, we cleaned

\footnotetext{
${ }^{4}$ The selection of $10 \%$ of the total of the document is justified by the enormous work of cleaning the text, which must necessarily be carried out manually with the Word program as a step prior to the analysis with the INFLESZ program.
}

the text, which was necessary for final analysis through the computer software. Third, each of the 595 management report fragments, already cleaned, were copied into the INFLESZ program ${ }^{5}$ to obtain the number of syllables, words, sentences and, finally, the Fernández Huerta index value.

Regarding the text-cleaning step, several adjustments were made in each fragment. Periods that would generate fictitious sentences were eliminated, as were punctuation marks that generated additional sentences - that is, they cut sentences (e.g., dashes, parentheses, brackets, etc.). All numbers, symbols, abbreviations and acronyms were also replaced by their text equivalents.

\subsection{Variable measurements}

\subsubsection{Dependent variable: Readability}

The variable to be explained in our work was readability, measured by the Fernández Huerta index (Fernández Huerta, 1959). This index is an adaptation of the Flesch index for application to Spanish texts and takes into account word length (number of syllables per word) and sentence length (number of words per sentence) to determine the reading ease or difficulty. The word factor measures semantic difficulty and recognition speed, while the sentence factor quantifies the burden on short-term memory (Adelberg, 1979; Smith \& Taffler, 1992).

This adaptation is justified because the Flesch index is designed for English texts and its direct application to Spanish texts is inappropriate because English words are shorter, and Spanish uses longer sentences. The Fernández Huerta index is calculated as follows:

$$
\text { Fernndez Huerta index }=206.835-0.6 \cdot w l-1.02 \cdot s l
$$

where $\mathrm{wl}$ is the average length of the words (measured in syllables per word and multiplied by 100) and sl is the average length of the sentences (measured in words per sentence).

This produces a score between 0 and 100 points. The lower end indicates a very difficult text to read, typical of scientific texts, and the upper end indicates a very easy to read text. Table 2 illustrates the full scale for this index.

Table 2

Readability scores and their correlation with typical magazines

\begin{tabular}{llll}
\hline Score & Difficulty & Educational level & Typical magazine \\
\hline $90-100$ & Very easy & Grade 5 & Comics \\
$80-90$ & Easy & Grade 6 & Pulp fiction \\
$70-80$ & Fairly easy & Grade 7 & Slick fiction \\
$60-70$ & Standard & Grades 8-9 & Digests \\
$50-60$ & Fairly difficult & Grades 10-12 & Quality \\
$30-50$ & Difficult & Undergraduate degree & Academic \\
$0-30$ & Very difficult & Postgraduate degree & Scientific \\
\hline
\end{tabular}

Adapted from Flesch (1948).

\subsubsection{Independent variables}

Quantity of text was the first variable considered, measured as the log of text words contained in each management report. It is expected that larger reports have a lower readability score, since longer texts require higher informationprocessing costs and also the length of a report could be used strategically by managers in order to make this report less transparent and to hide adverse information from investors

\footnotetext{
${ }^{5}$ Available at: https://legibilidad.blogspot.com/2015/01/ el-programa-inflesz.html
} 
(Li, 2008). In addition, organisations such as the SEC have suggested that companies avoid lengthy sentences and documents (1998). Therefore, we expected a negative relationship between the text quantity contained in the management report and its readability, that is, those companies that use large quantities of text produce reports with lesser readability.

The second variable was the quantity of visual elements. Visual elements are contained in management reports to help the reader to better process the information (Van Beest, Braam, \& Boelens, 2009) and to organize the ideas in a clearer way. Management reports can therefore contain tables, charts, graphs, figures, maps, flowcharts and other graphics to facilitate readability. The main regulatory bodies (CNMV, 2013; IASB, 2010; IOSCO, 2003; SEC, 1998, among others) recommend the use of these visual resources. To measure the quantity of visual elements in each report, we compared the space occupied by visual elements to the space occupied by the rest of the information printed (i.e., text words and visual elements). This created a quantitative measure of the visual elements used in each report based on their proportion of the whole. We expected a positive relationship between the proportion of visual elements contained in the management report and its readability, since the use of visual elements will allow the creation of more readable texts.

The third variable was good governance practices, which measure the proportion of recommendations that a company has totally and partially complied with in its Annual Corporate Governance Report ${ }^{6}$, weighted by importance. The recommendations with which a company had totally complied were assigned a weight of 1 , and the recommendations with which a company had partially complied were weighted 0.5. The computation of good governance practices (GGP) is as follows:

$$
G G P=\frac{\text { recommendations totally complied with } \cdot 1}{\text { total recommendations }}
$$

+ recommendations partially complied with $\cdot 0.5$ - recommendations not applicable

We expected that companies that carry out a greater compliance with recommendations of corporate governance practices are those that issue more readable management reports.

\subsubsection{Control variables}

The control variables used in this work are related to the compliance with the CNMV guide for the elaboration of management reports and firm characteristics. These variables were CNMV guide, performance, size, leverage, age, corporate actions and qualified audit report.

The first control variable was compliance with the CNMV guide for the preparation of management reports, proposed by the National Stock Market Commission (CNMV, 2013). This guide recommends a series of sections that each report should contain, as well as several guidelines for publishing

${ }^{6}$ The Annual Corporate Governance Report is the component of annual financial statements that includes the follow-up that listed companies make regarding recommendations on good practices proposed in the codes of good governance through compliance with a standardised format required by the National Commission of the Stock Market. Each recommendation supports up to four of the following options: 'comply', 'partially comply', 'explain' and 'not applicable'. We will focus on the recommendations complied, both totally and partially, in relation to those that are applicable. the information in those sections. For use of the CNMV guide when preparing management reports, which establishes a management report structure with nine epigraphs, we used a dichotomous variable to separate the companies that follow the CNMV guide from those that do not. We expected a positive relationship between this variable and the readability of the management report, since the objective of the CNMV guide is for companies to publish reports that are more transparent and therefore more readable.

Performance was measured as the return on assets, defined by the earnings before interest and taxes (EBIT) divided by total assets. Following previous studies that found a positive relationship between performance and readability (Ajina et al., 2016; Dempsey et al., 2012; Li, 2008; Subramanian, Insley, \& Blackwell, 1993), we expected that companies with better profits would produce more readable reports so that stakeholders would be aware of their good performance.

Following Courtis (1995), Li (2008), Lo et al. (2017), Rutherford (2003), Smith et al. (2006) and Suárez Fernández (2013, 2016), the third control variable was company size. This variable was computed as the log of the average number of workers. Large companies have more complex operations to report and thus produce more complex narratives (Ajina et al., 2016; Jones, 1988; Li, 2008; Lim et al., 2018). We therefore expected that larger companies would issue less readable reports, so the relationship will be negative. However, large companies also have more resources to spend on producing clearer reports than small companies and, therefore, may produce more readable reports (Courtis, 1995; Drago, Ginesti, Pongelli, \& Sciascia, 2018). Considering both approaches, we expected both negative and positive relationships depending on whether operational complexity or information clarity would prevail when companies prepared their management reports (Lo et al., 2017).

The degree of leverage, quantified as the quotient of the total debt of the company and its total assets, was another control variable (Courtis, 1986; Rutherford, 2003; Smith et al., 2006). Firms with more debt in their capital structure may have more complex disclosures when explaining all the information related to their debt structure. Following previous studies (Ajina et al., 2016; Dempsey et al., 2012; Rutherford, 2003; Smith \& Taffler, 1992), we expected a negative relationship between a company's level of indebtedness and the readability of its reports.

We used the age of the company as the fifth control variable, measured by the log of the age. Older companies have fewer information asymmetries and, therefore, less uncertainty in the elaboration of information owing to accumulated experience, so their reports may be simpler and more readable ( $\mathrm{Li}, 2008)$. However, it is also true that older companies tend to be larger and have more complex operations, so they may produce more complicated reports that are therefore less readable. Consequently, we expected both positive and negative relationships, depending on whether information asymmetries or the complexity of operations determined the greater or lesser readability of management reports ( $\mathrm{LO}$ et al., 2017).

Ownership dispersion was the sixth control variable used, defined as the proportion of shares held by the public (Ajina et al., 2016). Following the agency theory, if the ownership structure is more dispersed, agency costs increase because of the increased probability of conflict of interest between owners (Jensen \& Meckling, 1976). We expected that firms with high ownership dispersion would be likely to issue more readable management reports (Ajina et al., 2016; Oliveira, Lima Rodrigues, \& Craig, 2006). 
To reflect the effect that corporate actions may have on the readability of management reports, public offerings and takeover bids were considered. A dichotomous variable was created with the value one if the company has made a public offer or received a takeover bid during the corresponding year and the value zero otherwise. These types of complex operations require greater effort to explain the company's performance in that year and, therefore, we expected less readable management reports (Li, 2008).

We also included the dichotomous variable of a qualified audit report, which was given the value of one if the company received the audit report with qualifications and zero if it was an unqualified audit report. It is possible that companies have obtained a qualified audit as a result of having published complex and not very transparent reports. We therefore expected a negative relationship between this variable and readability.

Table A1 of the appendix contains the descriptive statistics of all the variables used in our study (i.e., dependent, independent and control variables), both measured in scalar terms and dichotomised.

Finally, we included sector and year dummies as control variables to measure the industry and temporary effects in all the proposed relationships.

\subsection{Models and methodology}

The first objective of the paper is to analyse whether the amount of text (H2) and visual elements (H3) that determine the extension of management reports, explain the readability of these reports. To analyse these relationships, the following model was proposed:

$$
F H I_{i t}=\beta_{0}+\beta_{1} \cdot T Q_{i t}+\beta_{2} \cdot Q V E_{i t}+\Sigma \beta_{j} \cdot C V j_{i t}+\varepsilon_{i t}
$$

where $F H I_{i t}$ is the Fernández Huerta index of the management report for company $i$ in year $t$; $T Q_{i t}$ is the text quantity contained in the management report of company $i$ in year $t$, quantified by the log of text words; $Q V E_{i t}$ is the quantity of visual elements contained in the management report of company $i$ in year $t$, measured by the proportion of visual elements; and $C V j_{i t}$ is the corresponding control variable $j$ of company $i$ in the year $t$, which has been previously described. Finally, $\varepsilon_{i t}$ is the error term, which is split into three components: the individual effect $\left(\eta_{i}\right)$, the temporal effect $\left(d_{t}\right)$ and white noise or random disturbance $\left(v_{i t}\right)$.

The second objective of the research is to examine to what extent the compliance of good governance practices (H4) explains the readability of management reports. To do this, the good governance practices variable was incorporated into the previous proposed model:

$$
F H I_{i t}=\beta_{0}+\beta_{1} \cdot T Q_{i t}+\beta_{2} \cdot Q V E_{i t}+\beta_{3} \cdot G G P_{i t}+\Sigma \beta_{j} \cdot C V j_{i t}+\varepsilon_{i t}
$$

where $G G P_{i t}$ represents good governance practices of company $i$ in year $t$, quantified through the proportion of complied recommendations in its annual corporate governance report. The rest of the variables have been previously defined in model (1).

We estimated all models using panel data methodology. The use of panel data estimations allows us to control for individual effects or unobserved heterogeneity. We controlled this heterogeneity in companies to avoid biased results by modelling it as individual effects, $\eta_{i}$. In particular, we used random effects models with the Feasible Generalised Least Squares (FGLS) estimator.
Before beginning the analysis, we also ran several tests to choose the method of estimation. First, we ran the BreuschPagan test, to check that a panel data model would be preferable to a pool of data. Second, we ran the Hausman test to compare the Within Groups (WG) estimator in fixed effects and the FGLS estimator in random effects, under the null hypothesis that the difference in coefficients is not systematic. We cannot reject the null hypothesis, so the FGLS estimator in random effects is preferable because it is more efficient. Finally, we ran the Pesaran test of cross-sectional independence, the Wooldridge test for autocorrelation and the Wald test for group-wise heteroscedasticity. All models had no cross-sectional dependence and no autocorrelation but heteroscedasticity, so they accounted for heteroscedasticity in residual distribution.

\section{Results}

Table 3 illustrates the descriptive statistics and score distribution of the Fernández Huerta index by year. As can be seen, the data indicate that the mean (median) moves between the values $47.38-48.67(48.13-49.95)$ and the distribution of the score is concentrated between the difficult and fairly difficult scores, which correspond respectively to the scoring ranges 30-50 and 50-60. These results are in line with previous studies such as Jones (1988), Courtis (1995), Hynes and Bexley (2004) and Moreno \& Casasola (2016) for the Spanish case. In addition, these mean and median values are relatively stable over the years analysed, according to the Friedman test, so hypothesis H1 is corroborated. Suárez Fernández (2016) also found that readability was similar during his period of study (i.e., the years 2007, 2008 and 2009).

Table 3

Descriptive statistics and score distribution of Fernández Huerta index by years

\begin{tabular}{lccccccc}
\hline \multicolumn{1}{c}{ Year } & 2010 & 2011 & 2012 & 2013 & 2014 & 2015 & 2016 \\
\hline \multicolumn{7}{c}{ Panel A: Descriptive statistics } \\
Mean & 48.26 & 47.38 & 47.68 & 48.26 & 48.36 & 48.67 & 48.47 \\
Std. dev. & 9.92 & 8.77 & 9.39 & 8.84 & 9.67 & 8.11 & 8.67 \\
Min & 18.71 & 16.47 & 6.26 & 17.57 & 18.85 & 20.56 & 24.09 \\
$1^{\text {st }} \mathrm{Q}$ & 43.69 & 42.51 & 42.28 & 43.91 & 44.01 & 44.64 & 43.85 \\
Median & 49.80 & 48.92 & 48.76 & 49.21 & 49.95 & 48.95 & 48.13 \\
$3^{\text {er }} \mathrm{Q}$ & 54.61 & 52.79 & 53.30 & 53.06 & 53.91 & 53.37 & 52.29 \\
Max & 63.65 & 69.07 & 70.30 & 69.69 & 67.59 & 64.60 & 72.53 \\
$\mathrm{~N}$ & 83 & 86 & 87 & 87 & 87 & 84 & 81 \\
Friedman test & & & & 2.092 & & & \\
& & & & $0.351)$ & & & \\
Very easy (90-100) & 0 & 0 & 0 & 0 & 0 & 0 & 0 \\
Easy (80-90) & 0 & 0 & 0 & 0 & 0 & 0 & 0 \\
Fairly easy (70-80) & 0 & 0 & 1.15 & 0 & 0 & 0 & 1.24 \\
Standard (60-70) & 7.23 & 2.33 & 5.75 & 10.35 & 8.05 & 4.76 & 7.41 \\
Fairly difficult (50-60) & 42.17 & 41.86 & 37.93 & 31.03 & 40.23 & 41.67 & 29.63 \\
Difficult (30-50) & 44.58 & 50.00 & 52.87 & 54.02 & 44.83 & 51.19 & 58.03 \\
Very difficult (0-30) & 6.02 & 5.81 & 2.30 & 4.60 & 6.90 & 2.38 & 3.70 \\
Total & 100.00 & 100.00 & 100.00 & 100.00 & 100.00 & 100.00 & 100.00 \\
\hline
\end{tabular}

This table presents the descriptive statistics and score distribution of the Fernández Huerta index by years. The Friedman test allows us to test whether the median is equal in all years.

Table A2 of the appendix provides the correlation matrix and the variance inflation factors (VIFs) between the independent and control variables used in the models presented above and allows us to examine the possible problems of multicollinearity. The results indicate that there are no problems of multicollinearity (between the independent and control variables), as well as their possible negative consequences on the regression analysis, because although there are some sig- 
nificant correlations between independent variables, all are well below 0.7 (Tabachnick \& Fidell, 1996). Specifically, they are between 0.377 and 0.544 . In addition, all the VIFs of the explanatory variables (independent and control) are close to one.

After verifying that there were no problems of multicollinearity between the independent and control variables, we studied the relationships proposed previously through the regression models. We analysed the relationships between text quantity and the readability of management reports and between the quantity of visual elements and readability in regression (1), after controlling for several factors. Next, we incorporated the variable measuring good governance practices in regression model (2). Table 4 illustrates the results of the regressions obtained for the Fernández Huerta index with respect to the two variables that measure the extension of management reports (i.e., quantity of text and visual elements) and with respect to good governance practices. The estimates were carried out through random effects.

Table 4

Influence of text, visual elements and good governance practices on readability

\begin{tabular}{|c|c|c|c|}
\hline \multirow{2}{*}{ Dependent variable } & \multirow[b]{3}{*}{$\begin{array}{l}\text { Predicted } \\
\text { sign }\end{array}$} & (1) & \multirow{2}{*}{$\begin{array}{c}\text { (2) } \\
\text { Fernández Huerta } \\
\text { index }\end{array}$} \\
\hline & & $\begin{array}{c}\text { Fernández Huerta } \\
\text { index }\end{array}$ & \\
\hline Independent variable & & Coefficient (p-value) & Coefficient (p-value) \\
\hline Intercept & & $64.912 * * *(0.000)$ & $55.226 * * *(0.000)$ \\
\hline Text quantity & - & $-1.754 * *(0.012)$ & $-1.847 * * *(0.009)$ \\
\hline Quantity of Visual elements & + & $7.261 * *(0.036)$ & $6.726 * *(0.046)$ \\
\hline Good governance practices & + & & $12.483 *(0.071)$ \\
\hline \multicolumn{4}{|l|}{ Control variables } \\
\hline CNMV guide & + & $2.334 *(0.094)$ & $2.468 *(0.080)$ \\
\hline Performance & + & $-0.024(0.982)$ & $0.201(0.850)$ \\
\hline Firm size & $-1+$ & $0.291(0.280)$ & $0.200(0.472)$ \\
\hline Leverage & - & $-3.982 * * *(0.001)$ & $-3.607 * * *(0.004)$ \\
\hline Age & $-1+$ & $0.023(0.980)$ & $0.156(0.865)$ \\
\hline Ownership dispersion & + & $-0.125(0.950)$ & $-1.177(0.582)$ \\
\hline Corporate actions & - & $1.264(0.535)$ & $1.518(0.457)$ \\
\hline Qualified audit report & - & $1.075(0.453)$ & $1.561(0.301)$ \\
\hline Sector dummies & & Yes & Yes \\
\hline Year dummies & & Yes & Yes \\
\hline Observations/Groups & & $595 / 87$ & $595 / 87$ \\
\hline Wald test & & $47.48^{* * *}(0.001)$ & $46.09 * * *(0.001)$ \\
\hline Rho $(\rho)$ & & 0.1774 & 0.1778 \\
\hline
\end{tabular}

This table shows the regression results for the Fernández Huerta index. Independent and control variables are: text quantity (log text words); quantity of visual elements (proportion of visual elements); good governance practices (proportion of recommendations with which a company has totally and partially complied, weighted by the importance of each recommendation); CNMV guide (binary variable equal to one if the management report of firm is disclosure according to the guide proposed by the CNMV and zero otherwise); performance (return on assets); firm size (log of average number of workers); leverage (ratio of total debt to total assets); age (log firm age); ownership dispersion (proportion of shares held by the public); corporate actions (binary variable equal to one if the firm has made a public offering or has received a takeover bid and zero otherwise); and qualified audit report (binary variable equal to one if the audit report is issued with qualifications and zero otherwise). Both regressions include sector and year dummies. They have been estimated through random effects, using FGLS regressions. The Wald test measures the joint significance of the explanatory variables of the model. The rho coefficient $(\rho)$ computes the percentage contribution to the total variance of the panel data structure. ${ }^{*}$ Significant at $10 \% .{ }^{* *}$ Significant at $5 \% .{ }^{* * *}$ Significant at $1 \%$.
The results in regression (1) suggest that there is a negative and statistically significant relationship between the amount of text and the readability of management reports. This means that issuing a large amount of information by companies produces management reports that are more difficult to read. Longer management reports that present greater quantities of text are less readable than shorter ones, so hypothesis H2 is supported. These results are in line with the approaches of Bonsall et al. (2017), Li (2008), and Loughran \& McDonald (2014).

If we look at the use of visual elements in management reports, we can see how they have a positive and statistically significant influence on the readability of the report. The quantity of visual elements not only favours understanding of information from a global point of view (CNMV, 2013; IASB, 2006, 2010; IOSCO, 2003; SEC, 1998), but also allows companies to write more readable texts in the management reports. We can therefore conclude that hypothesis H3 is verified.

Finally, we incorporated the variable measuring good governance practices in regression model (2). The results obtained provide robustness to those shown in model (1). The relationship between the text quantity of a management report and its readability is negative and statistically significant, supporting hypothesis $\mathrm{H} 2$. The results also reveal again a positive and statistically significant relationship between the quantity of visual elements and the readability of the management reports, so hypothesis $\mathrm{H} 3$ is corroborated.

The main finding of this model (2) is that there is a relationship between good governance practices and readability, which is positive and statistically significant. Companies complying with a higher percentage of recommendations leads to the creation of an environment of greater trust and transparency (Mallin, 2013; OCDE, 2016). This greater transparency translates into clearer and more reliable information published by companies, including the management reports, which become more readable. In this way, compliance with good governance practices prevents the opportunistic behaviour of managers, who are tempted to take advantage of information asymmetries with respect to stakeholders (Cuomo, Mallin, \& Zattoni, 2016). We can therefore conclude that companies following good corporate governance practices issue management reports that are easier to read. These results verify hypothesis $\mathrm{H} 4$.

Regarding the control variables, we highlight the CNMV guide variable that appears to have a positive and significant relationship with the readability of the reports, revealing that the companies following the CNMV guide to elaborate their reports tend to issue more readable reports. The leverage variable is also statistically significant with a negative sign. Thus, more indebted companies tend to issue less readable management reports (Ajina et al., 2016).

Wald tests allow us to confirm the joint significance of the explanatory variables in models (1) and (2). The rho coefficients reveal that $17.74 \%$ and $17.78 \%$, respectively, of the variance in the models is due to the panel data structure.

\subsection{Robustness check}

In order to provide robustness to the results, the two regression models were processed again, using the Szigriszt index as an alternative measure of readability. The Szigriszt index is computed as follows:

Szigriszt index $=206.835-0.623 \cdot w l-1 \cdot s l$ 
Table 5 illustrates the regression models (1) and (2) for the Szigriszt index as a dependent variable. As can been seen, the results are similar to those obtained in Table 4 with the Fernández Huerta index. That is, there is a negative and statistically significant relationship between the amount of text in management reports and their readability (H2). The relationship between the use of visual elements and readability is positive and statistically significant (H3). Finally, it is confirmed again that good governance practices have a positive influence on the readability of the narrative information contained in the management report $(\mathrm{H} 4)$.

Table 5

Robustness check: Szigriszt index as readability measure

\begin{tabular}{|c|c|c|c|}
\hline \multirow{2}{*}{\multicolumn{2}{|c|}{ Dependent variable }} & (1) & (2) \\
\hline & & Szigriszt index & Szigriszt index \\
\hline Independent variable & $\begin{array}{l}\text { Predicted } \\
\text { sign }\end{array}$ & Coefficient (p-value) & Coefficient (p-value) \\
\hline Intercept & & $60.246 * * *(0.000)$ & $50.531 * * *(0.000)$ \\
\hline Text quantity & - & $-1.725 * *(0.013)$ & $-1.818^{* * *}(0.009)$ \\
\hline Quantity of Visual elements & + & $7.116 * *(0.039)$ & $6.578 *(0.050)$ \\
\hline Good governance practices & + & & $12.518 *(0.070)$ \\
\hline \multicolumn{4}{|l|}{ Control variables } \\
\hline CNMV guide & + & $2.254(0.104)$ & $2.388 *(0.088)$ \\
\hline Performance & + & $0.066(0.952)$ & $0.292(0.787)$ \\
\hline Firm size & $-1+$ & $0.284(0.289)$ & $0.192(0.487)$ \\
\hline Leverage & - & $-3.890 * * *(0.002)$ & $-3.514 * * *(0.005)$ \\
\hline Age & $-1+$ & $0.038(0.966)$ & $0.171(0.851)$ \\
\hline Ownership dispersion & + & $-0.105(0.958)$ & $-1.163(0.584)$ \\
\hline Corporate actions & - & $1.307(0.510)$ & $1.562(0.432)$ \\
\hline Qualified audit report & - & $1.182(0.402)$ & $1.671(0.259)$ \\
\hline Sector dummies & & Yes & Yes \\
\hline Year dummies & & Yes & Yes \\
\hline Observations/Groups & & $595 / 87$ & $595 / 87$ \\
\hline Wald test & & $46.81^{* * *}(0.001)$ & $45.52 * * *(0.002)$ \\
\hline Rho $(\rho)$ & & 0.1754 & 0.1759 \\
\hline
\end{tabular}

This table contains the regression results for the Szigriszt index. Independent and control variables are: text quantity (log text words); quantity of visual elements (proportion of visual elements); good governance practices (proportion of recommendations with which a company has totally and partially complied, weighted by the importance of each recommendation); CNMV guide (binary variable equal to one if the management report of firm is disclosure according to the guide proposed by the CNMV and zero otherwise); performance (return on assets); firm size (log of average number of workers); leverage (ratio of total debt to total assets); age (log firm age); ownership dispersion (proportion of shares held by the public); corporate actions (binary variable equal to one if the firm has made a public offering or has received a takeover bid and zero otherwise); and qualified audit report (binary variable equal to one if the audit report is issued with qualifications and zero otherwise). Both regressions include sector and year dummies. They have been estimated through random effects, using FGLS regressions. The Wald test measures the joint significance of the explanatory variables of the model. The rho coefficient $(\rho)$ computes the percentage contribution to the total variance of the panel data structure. ${ }^{*}$ Significant at $10 \%$. ${ }^{* *}$ Significant at $5 \%$. ${ }^{* *}$ Significant at $1 \%$.

Concerning the control variables in the regressions, the previous relationships observed with respect to CNMV guide and leverage variables are confirmed CNMV guide variable is about to be significant in model (1). That is, those companies that follow the CNMV guide issue more readable reports, while more indebted companies provide less readable management reports. Again, Wald tests confirm the joint significance of the explanatory variables in both regressions and rho coefficients reveal that $17.54 \%$ and $17.59 \%$, respectively, of the variance in the models is due to the panel data structure.

\section{Conclusions}

In this paper, we have analysed the readability of narrative information contained within the management reports of Spanish companies listed on the Continuous Market of the Madrid Stock Exchange during the period 2010-2016. We used a measure of readability adapted to the singularity of texts in Spanish, since the Flesch index was developed for English texts and its application in Spanish texts is meaningless. In particular, we applied the Fernández Huerta index, which is an adaptation to the Spanish of the original Flesch index. Once we obtained the Fernández Huerta index for each management report, we tried to determine whether readability changed over time and whether the quantity of text and visual elements affected readability after controlling for several factors. We also examined whether there is a relationship between good governance practices and readability.

Our results indicate that readability was very stable during the years analysed, in line with Suárez Fernández (2016). We also corroborated that text quantity has a negative impact on the readability of management reports: longer texts are less readable i.e., this finding lends support to the more generalist approaches of Bonsall et al. (2017), Li (2008), and Loughran \& McDonald (2014). However, the use of visual elements favours the presentation of more readable texts in management reports, according to regulatory bodies such as the CNMV (2013), IOSCO (2003), IASB (2006, 2010) and SEC (1998) that propose the use of visual elements to encourage companies to write simpler and more readable reports. There is also a positive and significant relationship between good governance practices and readability, which reveals that companies that follow a greater number of corporate governance practices issue more readable management reports. Good corporate governance improves the transparency of accounting narratives (Mallin, 2013; OCDE, 2016), communicating complex information with more clarity, speed, and simplicity (i.e., reports are more readable). Finally, regarding the control variables, we found that more indebted companies presented less readable management reports, while those that followed the CNMV guide issued more readable reports.

This study could not only be interest for those responsible for preparing financial information and stakeholders, but also for regulatory bodies. At the present time, where accounting information is expanding and increasingly complex, this paper provides empirical evidence that supports the projects and recommendations issued by several international organisations to improve the readability. Thus, our results are in line with the proposal made by the SEC (1998) that recommended limiting the size of the reports. We also agree with the recommendations of the CNMV (2013), the IOSCO (2003) and the IASB $(2006,2010)$ on the use of graphic resources, since the results indicate that visual elements improve readability of management reports. Finally, we propose, as a novelty, that compliance with good corporate governance practices improves the transparency of the accounting information, which translates into more readable reports.

\section{Funding}

This work was supported by the Ministry of Science and Innovation [PID2019-104304GB-I00/AEI/ 10.13039/501100011033]; and the University of La Rioja [REGI2020-48].

\section{Conflict of interests}

The authors declare no conflict of interests. 


\section{References}

Adelberg, A. H. (1979). A methodology for measuring the understandability of financial report messages. Journal of Accounting Research, 17(2), 565-592.

Ajina, A., Laouiti, M., \& Msolli, B. (2016). Guiding through the Fog: Does annual report readability reveal earnings management? Research in International Business and Finance, 38, 509-516. https://doi.org/10.1016/j.ribaf. 2016.07.021

Asay, S., Libby, R., \& Rennekamp, K. (2018). Firm Performance, Reporting Goals, and Language Choices in Narrative Disclosures. Journal of Accounting and Economics, 65(2-3), 380-398. https://doi.org/10.1016/j.jacceco.2018.02.002

Beattie, V., \& Davison, J. (2015). Accounting narratives: Storytelling, philosophising and quantification. Accounting and Business Research, 45(6-7), 655-660. https://doi.org/ 10.1080/00014788.2015.1081520

Beattie, V., \& Jones, M. J. (1997). A comparative study of the use of financial graphs in the corporate annual reports of major U.S. and U.K. companies. Journal of International Financial Management and Accounting, 8(1), 33-68. https: //doi.org/10.1111/1467-646X.00016

Beattie V., McInnes, B., \& Fearnley, S. (2004). A methodology for analysing and evaluating narratives in annual reports: A comprehensive descriptive profile and metrics for disclosure quality attributes. Accounting Forum, 28(3), 205236. https://doi.org/10.1016/j.accfor.2004.07.001

Beattie, V., \& Smith, S. J. (2013). Value creation and business models: Refocusing the intellectual capital debate. British Accounting Review, 45(4), 243-254. https://doi.org/10. 1016/j.bar.2013.06.001

Bonsall, S. B., Leone, A. J., Miller, B. P., \& Rennekamp, K. (2017). A plain English measure of financial reporting readability. Journal of Accounting and Economics, 63(2-3), 329357. https://doi.org/10.1016/j.jacceco.2017.03.002

Bravo, F., \& Reguera-Alvarado, N. (2017). Do independent director's characteristics influence financial reporting quality? Spanish Journal of Finance and Accounting / Revista Española de Financiación y Contabilidad, 47(1), 25-43. https: //doi.org/10.1080/02102412.2017.1362200

Bushee, B. J., Gow, I. D., \& Taylor, D. J. (2018). Linguistic Complexity in Firm Disclosures: Obfuscation or Information? Journal of Accounting Research, 56(1), 85-121. https://doi. org/10.1111/1475-679X.12179

Cerbioni, F., \& Parbonetti, A. (2007). Exploring the effects of corporate governance on intellectual capital disclosure: An analysis of European biotechnology companies. European Accounting Review, 16(4), 791-826. https://doi.org/10. 1080/09638180701707011

Clatworthy, M., \& Jones, M. J. (2001). The effect of thematic structure on the variability of annual report readability. Accounting, Auditing \& Accountability Journal, 14(3), 311326. https://doi.org/10.1108/09513570110399890

CNMV. (2013). Guía para la elaboración del informe de gestión de las entidades cotizadas.

Courtis, J. K. (1986). An Investigation into Annual Report Readability and Corporate Risk-Return Relationships. Accounting and Business Research, 16(64), 285-294. https: //doi.org/10.1080/00014788.1986.9729329

Courtis, J. K. (1987). Fry, Smog, Lix and Rix: Insinuations about corporate business communications. Journal of Business Communication, 24(2), 19-27. https://doi.org/10. $1177 / 002194368702400202$

Courtis, J. K. (1995). Readability of annual reports: Western versus Asian evidence. Accounting, Auditing \& Ac- countability Journal, 8(2), 4-17. https://doi.org/10.1108/ 09513579510086795

Cuomo, F., Mallin, C., \& Zattoni, A. (2016). Corporate Governance Codes: A Review and Research Agenda. Corporate Governance: An International Review, 24(3), 222-241. https://doi.org/10.1111/corg.12148

Dempsey, S. J., Harrison, D. M., Luchtenberg, K. F., \& Seiler, M. J. (2012). Financial Opacity and Firm Performance: The Readability of REIT Annual Reports. Journal of Real Estate Finance and Economics, 45(2), 450-470. https://doi.org/ 10.1007/s11146-010-9263-2

Dolphin, R., \& Wagley, R. A. (1977). Reading the annual report. Financial Executive, 45, 20-22.

Drago, C., Ginesti, G., Pongelli, C., \& Sciascia, S. (2018). Reporting strategies: What makes family firms beat around the bush? Family-related antecedents of annual report readability. Journal of Family Business Strategy, 9(2), 142-150. https://doi.org/10.1016/j.jfbs.2017.11.006

Fama, E. F., \& Jensen, M. C. (1983). Separation of Ownership and Control. Journal of Law \& Economics, XXVI(June), 301-325. https://doi.org/10.1086/467037

Fernández Huerta, J. (1959). Medidas sencillas de lecturabilidad [Simple measures of readability]. Consigna, 214, 29-32.

Fialho, A., Fuertes, Y., \& Pascual, E. (2002). La carta del presidente a sus accionistas. Partida Doble, 131, 52-63.

Flesch, R. (1948). A new readability yardstick. Journal of Applied Psychology, 32(3), 221-233. https://doi.org/10. 1037/h0057532

Ginesti, G., Drago, C., Macchioni, R., \& Sannino, G. (2018). Female board participation and annual report readability in firms with boardroom connections. Gender in Management, 33(4), 296-314. https://doi.org/10.1108/ GM-07-2017-0079

Guay, W., Samuels, D., \& Taylor, D. (2016). Guiding through the Fog: Financial statement complexity and voluntary disclosure. Journal of Accounting and Economics, 62(23), 234-269. https://doi.org/10.1016/J.JACCECO.2016.09. 001

Gunning, R. (1952). The technique of clear writing. New York, NY: McGraw-Hill.

Havemo, E. (2018). Visual trends in the annual report: the case of Ericsson 1947-2016. Corporate Communications: An International Journal, 23(3), 312-325. https://doi.org/10. 1108/CCIJ-03-2017-0015

Hopwood, A. G. (2007). Whither accounting research? Accounting Review, 82(5), 1365-1374. https://doi.org/10. 2308/accr.2007.82.5.1365

Hynes, G. E., \& Bexley, J. B. (2004). The Contribution of Banks' Annual Report Writing Quality to Investor DecisionMaking. Academy of Banking Studies Journal, 3(1-2), 113122.

IASB. (2006). Preliminary views on an improved conceptual framework for Financial Reporting: the objective of Financial Reporting and qualitative characteristics of decisionuseful Financial Reporting Information.

IASB. (2010). Management Commentary. A framework for presentation.

Instituto Cervantes. (2017). El español: Una lengua viva. Informe 2017. Madrid, Spain.

IOSCO. (2003). General Principles Regarding Disclosure of Management's Discussion and Analysis of Financial Condition and Results of Operations.

Jensen, M. C., \& Meckling, W. H. (1976). Theory of the firm: Managerial behavior, agency costs and ownership 
structure. Journal of Financial Economics, 3(4), 305-360. https://doi.org/10.1016/0304-405X(76)90026-X

Jones, M. J. (1988). A longitudinal study of the readability of the chairman's narratives in the corporate reports of a UK Company. Accounting and Business Research, 18(72), 297305. https://doi.org/10.1080/00014788.1988.9729377

Jones, M. J. (1997). Methodological themes: Critical appraisal of the cloze procedure's use in the accounting domain. Accounting, Auditing \& Accountability Journal, 10, 105-128. https://doi.org/10.1108/09513579710158739

Jones, M. J., \& Shoemaker, P. A. (1994). Accounting narratives: A review of empirical studies of content and readability. Journal of Accounting Literature, 13, 142-194.

Kaspereit, T., Lopatta, K., \& Onnen, D. (2017). Shareholder Value Implications of Compliance with the German Corporate Governance Code. Managerial and Decision Economics, 38(2), 166-177. https://doi.org/10.1002/mde. 2750

Lewis, N. R., Parker, L. D., Pound, G. D., \& Sutcliffe, P. (1986). Accounting report readability: The use of readability techniques. Accounting and Business Research, 16(63), 199213. https://doi.org/10.1080/00014788.1986.9729318

Li, F. (2008). Annual report readability, current earnings, and earnings persistence. Journal of Accounting and Economics, 45(2-3), 221-247. https://doi.org/10.1016/j. jacceco.2008.02.003

Lim, E. K., Chalmers, K., \& Hanlon, D. (2018). The influence of business strategy on annual report readability. Journal of Accounting and Public Policy, 37(1), 65-81. https: //doi.org/10.1016/J.JACCPUBPOL.2018.01.003

Liu, X., \& Zhang, C. (2017). Corporate governance, social responsibility information disclosure, and enterprise value in China. Journal of Cleaner Production, 142, 1075-1084. https://doi.org/10.1016/j.jclepro.2016.09.102

Lo, K., Ramos, F., \& Rogo, R. (2017). Earnings management and annual report readability. Journal of Accounting and Economics, 63(1), 1-25. https://doi.org/10.1016/j. jacceco.2016.09.002

Loughran, T., \& McDonald, B. (2014). Measuring readability in financial disclosures. Journal of Finance, 69(4), 16431671. https://doi.org/10.1111/jofi.12162

Mallin, C. (2013). Corporate governance (4th ed.). Oxford: Oxford University Press.

Moreno, A., \& Casasola, A. (2016). A Readability Evolution of Narratives in Annual Reports: A Longitudinal Study of Two Spanish Companies. Journal of Business and Technical Communication, 30(2), 202-235. https://doi.org/10. $1177 / 1050651915620233$

Ngai, C., \& Singh, R. (2014). Communication With Stakeholders Through Corporate Web Sites An Exploratory Study on the CEO Messages of Major Corporations in Greater China. Journal of Business and Technical Communication, 28(3), 352-394. https://doi.org/10.1177/1050651914524779

OCDE. (2016). Principios de Gobierno Corporativo de la OCDE y del G20. Ocde. https://doi.org/10.1787/ 9788485482726-es

Oliveira, L., Lima Rodrigues, L., \& Craig, R. (2006). Firmspecific determinants of intangibles reporting: Evidence from the Portuguese stock market. Journal of Human Resource Costing \& Accounting, 10(1), 11-33. https://doi.org/10. 1108/14013380610672657

PuchetaMartínez, M. C., \& NarroForés, C. (2014). La comisión de remuneraciones y las retribuciones de los consejeros. Academia Revista Latinoamericana de Administracion, 27(1), 46-74. https://doi.org/10.1108/ARLA-10-2013-0149

Rabin, A. T. (1988). Determining difficulty levels of text written in languages other than English. Newark, DE: International Reading Association.

Rutherford, B. A. (2003). Obfuscation, textual complexity and the role of regulated narrative accounting disclosure in corporate governance. Journal of Management and Governance, 7(2), 187-210. https://doi.org/10.1023/A: 1023647615279

Schroeder, N., \& Gibson, C. (1990). Readability of management's discussion and analysis. Accounting Horizons, 4, 78-87.

SEC. (1998). A plain English handbook. How to create clear SEC.

Smith, M., Jamil, A., Chik Johari, Y., \& Ahmar Ahmad, S. (2006). The chairman's statement in Malaysian companies: A test of the obfuscation hypothesis. Asian Review of Accounting, 14(1-2), 49-65. https://doi.org/10.1108/ 13217340610729464

Smith, M., \& Taffler, R. (1992). Readability and understandability: Different measures of the textual complexity of accounting narrative. Accounting, Auditing \& Accountability Journal, 5(4), 84-98. https://doi.org/10.1108/ 09513579210019549

Soper, F. J., \& Dolphin, R. (1964). Readability and corporate annual reports. Accounting Review, 39, 358-362.

Suárez Fernández, Ó. (2013). La claridad de la información narrativa en las empresas cotizadas españolas. Revista Galega de Economía, 21(1), 9-29.

Suárez Fernández, Ó. (2016). £Es Neutral La Información Sobre Resultados? Revista de Contabilidad, 19(2), 204-215. https://doi.org/10.1016/j.rcsar.2015.09.001

Subramanian, R., Insley, R. G., \& Blackwell, R. D. (1993). Performance and Readability: A comparision of Annual Reports of profitable and unprofitable corporations. Journal of Business Communication, 30(1), 49-61. https://doi.org/ https://doi.org/10.1177/002194369303000103

Szigriszt Pazos, F. (1992). Sistemas predictivos de legibilidad del mensaje escrito: Fórmula de perspicuidad. Universidad Complutense de Madrid, Spain.

Tabachnick, B., \& Fidell, L. (1996). Using Multivariate Statistics (3rd ed.). New York: HarperCollins.

Tarca, A., \& Seah, S. (2006). The Impact of Regulatory Framework on Management Commentary Reports. SSRN eLibrary. https://doi.org/10.2139/ssrn.962628

Van Beest, F., Braam, G., \& Boelens, S. (2009). Quality of Financial Reporting: measuring qualitative characteristics. NiCE Working Paper 09-108, (April), 1-41.

Velte, P. (2018). Does gender diversity in the audit committee influence key audit matters' readability in the audit report? UK evidence. Corporate Social Responsibility and Environmental Management, 25(5), 748-755. https://doi. org/10.1002/csr.1491

Wang, M. C. (2016). The relationship between environmental information disclosure and firm valuation: the role of corporate governance. Quality and Quantity, 50(3), 11351151. https://doi.org/10.1007/s11135-015-0194-0

Yekini, K. C., Adelopo, I., Andrikopoulos, P., \& Yekini, S. (2015). Impact of board independence on the quality of community disclosures in annual reports. Accounting Forum, 39(4), 249-267. https://doi.org/10.1016/j.accfor.2015.05. 004

Zattoni, A., \& Cuomo, F. (2008). Why adopt codes of good governance? A comparison of institutional and efficiency perspectives. Corporate Governance: An International Review, 16(1), 1-15. https://doi.org/10.1111/j.1467-8683. 2008.00661.x 


\section{APPENDIX}

Table A1

Summary statistics of variables

\begin{tabular}{lcccccccc}
\hline Scalar variable & Mean & Std. Dev. & Min & $1^{\text {st }} \mathbf{Q}$ & Median & $3^{\text {rd }} \mathbf{Q}$ & Max & $\mathbf{N}$ \\
\hline Fernández Huerta index & 48.148 & 9.041 & 16.256 & 43.614 & 49.158 & 53.362 & 72.534 & 595 \\
Szigriszt index & 46.823 & 8.984 & 12.868 & 39.204 & 44.745 & 49.017 & 68.189 & 595 \\
Text quantity & 8.524 & 0.822 & 6.303 & 7.896 & 8.461 & 9.030 & 10.884 & 595 \\
Quantity of visual elements & 0.139 & 0.129 & 0.000 & 0.014 & 0.117 & 0.229 & 0.650 & 595 \\
Good governance practices & 0.893 & 0.079 & 0.583 & 0.850 & 0.908 & 0.950 & 1.000 & 595 \\
Performance & 0.027 & 0.242 & -4.808 & 0.009 & 0.043 & 0.082 & 0.912 & 595 \\
Firm size & 7.872 & 2.094 & 1.946 & 6.635 & 7.673 & 9.485 & 12.564 & 595 \\
Leverage & 0.664 & 0.345 & 0.036 & 0.500 & 0.656 & 0.788 & 3.717 & 595 \\
Age & 3.728 & 0.812 & 0.000 & 3.219 & 3.807 & 4.263 & 5.673 & 595 \\
Ownership dispersion & 0.442 & 0.220 & 0.008 & 0.278 & 0.387 & 0.602 & 1.000 & 595 \\
\hline \multirow{2}{*}{ Dummy variable } & Frequency & \multicolumn{7}{c}{ Percentage } \\
& No & Yes & Total & No & Yes & Total & & \\
\hline CNMV guide & 520 & 75 & 595 & 87.39 & 12.61 & 100.00 & & \\
Corporate actions & 584 & 11 & 595 & 98.15 & 1.85 & 100.00 & & \\
Qualified audit report & 572 & 23 & 595 & 93.13 & 6.87 & 100.00 & & \\
\hline
\end{tabular}

This table presents the descriptive statistics for all the variables used. These variables are: Fernández Huerta index; Szigriszt index; text quantity (measured as the logarithm of the text words); quantity of visual elements (quantified as the proportion of visual elements); good governance practices (computed as the proportion of recommendations with which a company has totally and partially complied, weighted by the importance of each practice); performance (quantified as the return on assets); firm size (computed as the logarithm of the average number of workers); leverage (measured as the ratio of total debt to total assets); age (quantified as the logarithm of the firm age); ownership dispersion (computed as the proportion of shares held by the public); CNMV guide (measured as a binary variable equal to one if the management report of the firm is disclosed according to the guide proposed by the CNMV and zero otherwise); corporate actions (quantified as a binary variable equal to one if the firm has made a public offering or has received a takeover bid and zero otherwise); and qualified audit report (measured as a binary variable equal to one if the audit report is issued with qualifications and zero otherwise).
Table A2

Correlation matrix and variance inflation factors

\begin{tabular}{|c|c|c|c|c|c|c|c|c|c|c|c|}
\hline Variables & 1 & 2 & 3 & 4 & 5 & 6 & 7 & 8 & 9 & 10 & 11 \\
\hline 1. TQ & 1.000 & & & & & & & & & & \\
\hline 2. QVE & 0.358 & 1.000 & & & & & & & & & \\
\hline 3. GGP & $\underset{* * * *}{0.273}$ & $\begin{array}{c}0.190 \\
* * * *\end{array}$ & 1.000 & & & & & & & & \\
\hline 4. CNMVG & $\underset{* * *}{0.322}$ & 0.024 & -0.001 & 1.000 & & & & & & & \\
\hline 5. $P$ & 0.035 & 0.035 & -0.018 & 0.029 & 1.000 & & & & & & \\
\hline 6. FS & $\underset{* * *}{0.544}$ & $\underset{* * * * 328}{0.328}$ & $\underset{* \ldots \ldots *}{0.313}$ & $\underset{* .123}{0.12 *}$ & $\underset{* 142}{0.142}$ & 1.000 & & & & & \\
\hline 7. $\mathrm{L}$ & $\underset{* * * *}{0.132}$ & -0.038 & -0.024 & 0.056 & $\underset{\substack{* \ldots * * \\
* * *}}{-0.377}$ & $\begin{array}{c}0.074 \\
*\end{array}$ & 1.000 & & & & \\
\hline 8. A & $\underset{* * * *}{-0.126}$ & -0.103 & $\underset{* * * *}{-0.218}$ & $\begin{array}{c}0.074 \\
*\end{array}$ & 0.032 & $\begin{array}{c}-0.185 \\
* * * *\end{array}$ & $\underset{* * *}{-0.149}$ & 1.000 & & & \\
\hline 9. OD & 0.305 & -0.007 & 0.291 & 0.036 & -0.085 & -0.120 & 0.180 & -0.004 & 1.000 & & \\
\hline 10. CA & 0.017 & 0.054 & -0.027 & 0.061 & -0.023 & -0.019 & 0.031 & -0.038 & -0.054 & 1.000 & \\
\hline 11. QAR & $\underset{\substack{* * * * \\
* * *}}{-0.142}$ & 0.002 & -0.209 & 0.029 & -0.242 & $\begin{array}{l}-0.204 \\
* * * *\end{array}$ & $\underset{\substack{* 1 * * * \\
* \ldots *}}{0.154}$ & 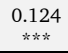 & 0.035 & -0.028 & 1.000 \\
\hline VIF & 1.88 & 1.25 & 1.31 & 1.17 & 1.26 & 1.61 & 1.30 & 1.13 & 1.25 & 1.02 & 1.17 \\
\hline
\end{tabular}

This table contains the Pearson correlation coefficients and the variance inflation factors (VIFs) between the independent and control variables. These variables are: TQ (text quantity) measured as the logarithm of the text words; QVE (quantity of visual elements) quantified as the proportion of visual elements; GGP (good governance practices) computed as the proportion of recommendations with which a company has totally and partially complied, weighted by the importance of each practice; CNMVG (CNMV guide) measured as a binary variable equal to one if the management report of the firm is disclosed according to the guide proposed by the CNMV and zero otherwise; P (performance) quantified as the return on assets; FS (firm size) computed as the logarithm of the average number of workers; L (leverage) measured as the ratio of total debt to total assets; A (age) quantified of the logarithm of the firm age; OD (ownership dispersion) computed as the proportion of shares held by the public; CA (corporate actions) measured as a binary variable equal to one if the firm has made a public offering or has received a takeover bid and zero otherwise; and QAR (qualified audit report) quantified as a binary variable equal to one if the audit report is issued with qualifications and zero otherwise. A VIF close to one reveals that there are no collinearity problems between the independent and control variables. ${ }^{*}$ Significant at $10 \%$. ${ }^{* *}$ Significant at $5 \%$. ${ }^{* * *}$ Significant at $1 \%$. 